\title{
On the Authenticity of the Mystical Treatise Tartīb al-Sulūk ascribed to Al-Qushayrīi
}

\author{
Eliyahu Stern \\ Department of Islamic and Middle Eastern Studies \\ The Hebrew University of Jerusalem
}

\section{Introduction}

During the 196os, Meier, Al-Samarrai, and Hasan published separate editions of a short Sufi treatise entitled Tartīb Al-Sulūk (henceforth Tartīb), dealing with the remembrance of God (dhikr). ${ }^{2}$ All three ascribed the treatise to the well known Sufi author Abū al-Qāsim 'Abd al-Karīm b. Hawāzin al-Qushayrī (376/986-465/1072). Other prominent scholars of Sufism, such as Massignon, Schimmel, and Gramlich, also number the Tartīb among al-Qushayrì's writings. Massignon did so as early as 1924, thereby preceding the other publications noted above. The Tartīb is also mentioned as a work by al-Qushayrī in both editions of the Encylopaedia of Islam. Meier and Malamud regard the Tartīb as a major source for studying

1 This article is an extended and revised version of a paper published in Hebrew in memory of the late Prof. Hava Lazarus-Yafeh. I am deeply grateful to Prof. Etan Kohlberg for his valuable comments on an earlier version of this study. Thanks also to Prof. Yohanan Friedmann and Prof. Sara Sviri for their advice.

2 F. Meier, "Qušayrì's Tartīb As-sulūk", Oriens 16 (1963), pp. 1-39 (including an introduction and a German translation. For an English version of the article see: F. Meier, Essays on Islamic Piety and Mysticism, trans. J. O'kane with editorial assistance of B. Radtke, [Leiden - Boston - Köln, 1999], pp. 93-133); Q. al-Samarrai, The Theme of Ascension in Mystical Writings, (Baghdad, 1968), pp. 156-182 (including an introduction and an abridged English translation); 'Abd l-Karīm al-Qushayrī, al-Rasā'il al-Qushayriyya, ed. [pir] Muḥammad Hasan (Pakistan, 1964), pp. 63-80 (I am grateful to Prof. Paul Fenton for sending me a section of this publication that includes the Tartīb). For Meier's discussion and remarks regarding the editions of Al-Samarrai and Hasan see: F. Meier, "Khurāsān and the End of Classical Sufism", in F. Meier, Essays on Islamic Piety and Mysticism, pp. 190-199. 
the development of the educational system (especially Sufi education) in the eleventh century. ${ }^{3}$

Prof. Hava Lazarus-Yafeh had suspected many years ago that the ascription of this work to al-Qushayrī was problematic and suggested I should explore this issue. My study did indeed find this ascription to be mistaken.

\section{Al-Qushayrī ${ }^{4}$}

Abū l-Qāsim 'Abd l-Karīm b. Hawāzin al-Qushayrī (376/986-465/1072) was born to a family of notables in the Ustuwā region next to Nishapur, the large district town in Khurasan. He moved to Nishapur in his youth, and later became prominent among its scholars and leaders. Two main factions,

3 C. Brockelmann, Geschichte der Arabischen Litteratur (Leiden, 1943), vol. 1, p. 556, Appendix 1, p. 772; L. Massignon, "Kushayr””, EI1 4 (1987), p. 116o; H. Halm, "al-Kushayrī", EI², (1986), vol. 5, p. 527; 'Abd al-Karim Al-Qušayri, Das Sendschreiben Al-Qušayrīs über das Sufitum, eingeleitet, übersetzt und kommentiert von R. Gramlich (Wiesbaden, 1989), pp. 16-17; A. Schimmel, Mystical Dimensions of Islam (Chapel Hill, 1975), p. 173; H. Ritter, "Philologica XIII", Oriens 3 (1950), p. $5^{0 .}$ Ritter added a question mark next to al-Qushayri’s name; M.I. Waley, "Contemplative disciplines in early Persian sufism", in L. Lewisohn (ed.), Classical Persian Sufism from Its Origins to Rumi (London and New York, 1993), p. 531. Waley notes that the work was ascribed to al-Qushayrī, and refers readers to Meier; M. Malamud, "Sufi Organizations and Structures of Authority in Medieval Nishapur", International Journal of Middle East Studies 26 (1994), pp. 429-437; A. Keeler, "Șūfī tafsīr as a Mirror: al-Qushayrī the murshid in his Lațā'if al-ishārāt", Journal of Qur'anic Studies 8 (2006), p. 17.

4 Studies on Sufism recurrently mention al-Qushayrī. For a number of extensive descriptions see R. Hartmann, Al-Kuschairîs Darstellung des Sûfitums, mit Uebersetzungs Beilage und indices (Berlin, 1914); A.J. Arberry, "Al-Qushairi as traditionalist”, Studia orientalia loanni Pedersen (Hauniae, 1953), pp. 12-20; Q. AlSamarrai, The Theme of Ascension in Mystical Writings, particularly pp. 29-50; 'Ibrāhim Basyūnī, al-'Imām al-Qushayrī: Sīratuhu, 'Āthāruhu, Madhhabuhu $f i$ al-Tașawwuf (Cairo, 1972); R.W. Bulliet, The Patricians of Nishapur: A Study in Medieval Islamic Social History (Cambridge, Mass. 1972), pp. 149-159; 'Abd al-Karim Al-Qušayri, Das Sendschreiben Al-Qušayrīs über das Sufitum, eingeleitet, übersetzt und kommentiert von R. Gramlich, pp. 1-18; Al-Qushayrī, Principles of Sufism, trans. B.R. Von Schlegell, introduction: H. Algar (Berkeley, 1990), pp. i-xvii; J.A. Mojaddedi, "Legitimizing Sufism in al-Qushayrī's Risāla", Studia Islamica 90 (2000), pp. 37-50; A. Keeler, "Șūfī tafsīr as a Mirror: al-Qushayrī the murshid in his Lațāiif al-ishārāt", Journal of Qur'ānic Studies 8 (2006); E. Stern, Protection From Sin in al-Qushayr’’s Thought, PhD. Dissertation [Hebrew] (Jerusalem, 2010). 
the Shāficites and the Hanafites, competed for power in the city. Many Shāfi ite leaders, including al-Qushayrī, were Ash'arites and Sufis, and many Hanafite leaders held $\mathrm{Mu}$ 'tazilite views, had contacts with elements showing Shīite proclivities, and at times worked alongside the Karrāmites, who were generally opposed to both factions. ${ }^{5}$

In the mid-eleventh/fifth century, in the days of Sultan Țughril Beg and his vizier 'Amīd al-Mulk al-Kundurī, the balance tilted against the Shāfíites. Their Ash'arite leaders were removed from positions of influence and their doctrines were publicly repudiated. Al-Qushayrī, who was among the prominent Ash'arites, brought out writings in their defense, debated their opponents, and even represented them in court. ${ }^{6}$ After a month of

5 For several studies of the various groups in Nishapur in general and of the mystical trends in particular see: Abū al-'Alā 'Afî̀i, al-Malāmatiyya wa-al-Ṣūfiyya wa-'Ahl al-Futuwwa (Cairo, 1954); C.E. Bosworth, "The Rise of the Karāmiyyah in Khurasan", The Muslim World 5o (1960), pp. 5-14; Q. Al-Samarrai, The Theme of Ascension in Mystical Writings, pp. 20-24; H. Halm, "Der Wesir Al-Kundurī und die Fitna von Nī̌āaūr", Die Welt des Orients 6 (1971), p. 217; R.W. Bulliet, The Patricians of Nishapur; C.E. Bosworth, The Ghaznavids-Their Empire in Afghanistan and Eastern Iran 994:1040 (Beirut, 1973), pp. 163-200; R.W. Bulliet, "The PoliticalReligious History of Nishapur in the Eleventh Century", Islamic Civilisation 9501150, ed. D.S. Richards (Oxford, 1973); J. Chabbi, "Remarques sur le développement historique des mouvements ascétiques et mistiques au Khurasan", Studia Islamica 46 (1977), pp. 5-72; W. Madelung, Religious Trends in Early Islamic Iran (New York, 1988), pp. 26-53; A. Zysow, "Two Unrecognized Karrāmī Texts”, Journal of The American Oriental Society 108 (1988), pp. 577-587; S. Sviri, "Hakīm Tirmidhī and the Malāmatī Movement in Early Sufism”, Classical Persian Sufism: From Its Origins to Rumi, ed. L. Lewisohn, New York 1993, pp. 583-613; M. Malamud, "Sufi Organizations and Structures of Authority in Medieval Nishapur", International Journal of Middle East Studies 26 (1994), pp. 427-442; M. Malamud, "The Politics of Heresy in Medieval Khurasan:The Karramiyya in Nishapur", Iranian Studies 27 (1994), pp.37-51; C. Melchert, "Sufi and Competing Movements in Nishapur", Iran 39 (2001), pp. 237247; S. Sviri, "The Early Mystical Schools of Baghdad and Nīshāpūr: in Search of Ibn Munāzil", Jerusalem Studies in Arabic and Islam 30 (2005), pp. 450-482; E. Stern, Protection From Sin in al-Qushayrìs Thought, pp. 9-63.

6 Abū al-Qāsim 'Ali b. al-Hasan b. 'Asākir, Tabyīn kidhb al-muftari fìmā nusiba 'ilā al-'Imām al-'ash'arī (Beirut, 1991), pp. 108-115, 274; 'Abd al-Wahhāb b. 'Ali al-Subkī, Ṭabaqāt al-Shāfíiyya al-Kubrā, ed. Maḥmūd Muḥammad al-Ṭanāḥ̄ and 'Abd al-Fattāh al-Ḥulwu (Cairo, 1964-1972), vol. 3, pp. 374-375, 390-393, 399-423; H. Halm, "Der Wesir Al-Kundurī und die Fitna von Nīšāpūr"; Q. Al-Samarrai The Theme of Ascension in Mystical Writings, pp. 50-54, 60; F. Meier, Abū Saīd-I Abū l-Hayr (357-440/967-1049), Wirklichkeit und Legende (Leiden, 1976), p. 263; W. Madelung, Religious Trends in Early Islamic Iran, p. 33; M. Cook, Commanding Right and 
imprisonment he was exiled from the city, and during the following years he lived with his family in the city of Țūs, spending considerable time in the district of his birth, Ustuwā, and teaching in different cities. Particularly well known is his stay in Baghdad where he taught and preached under the patronage of the Caliph al-Qā'im bi-'amr Allāh. ${ }^{7}$ In 1063, with the rise to power of Sultan Alp Arslān and his vizier Nizāam al-Mulk, who sympathized with the Ash'arites, al-Qushayrī returned to Nishapur, where he lived until his death.

Al-Qushayrī was reputed for his studies of Hadith, Islamic law according to the Shāfi'te school, Ash'arite theology and Sufism, as well as of poetry, and linguistics. His celebrity rests mainly on his role as one of the more outstanding mediators between the traditional world of Shari ${ }^{-} a$ and Ash'arite theology on the one hand, and Sufism on the other. By virtue of his teaching and his writings, where he repeatedly attacks antinomian trends in Sufism and posits, as a condition for the progress along the mystical path, the strict observance of all the commandments, al-Qushayri assumed a crucial role in the development of a moderate Islamic mysticism that demanded rigorous observance of the Sharīa.

His writings were studied, copied, and distributed already in his lifetime, and some have remained highly popular. Foremost among them is his Al-Risāla al-Qushayriyya fì 'ilm al-Tașawwuf (henceforth Risāla), perhaps the most famous and widespread Sufi work to this day. Al-Qushayri's many writings and numerous disciples considerably influenced Sufi thought in later times. Among celebrated mystics who surely knew his writings: al-Hujwīīi (d. between 465/1072-469/1077), al-Ghazālī (d. 505/1111), Kubrā (d. 617/1220), Ibn al-'Arabī (d. 638/1240), and Rūmī (d. 672/1273). ${ }^{8}$ His fame

Forbidding Wrong in Islamic Thought (Cambridge 2000), p. 346; E. Stern, Protection From Sin in al-Qushayri’s Thought, pp. 52-61.

7 Abū Bakr 'Aḥmad al-Khațīb al-Baghdādī, Ta'rīkh Baghdād (Beirut, 1997), vol. 11, p. 83; Ibn 'Asākir, Tabyīn kidhb al-muftarī fimā nusiba 'ilāal-'Imāmal-'ash'arī, p. 275; Q. Al-Samarrai, The Theme of Ascension in Mystical Writings, pp. 57-59; H. Halm, "Der Wesir Al-Kundurī und die Fitna von Nǐšāpūr", p. 231; R.W. Bulliet, The Patricians of Nishapur, p. 153.

8 Al-Hujwīrī mentions al-Qushayrī in numerous places in his book, Kashf alMahjúb, including an entry dedicated to al-Qushayrī. See: 'Alī b. 'Uthmān al-Jullābī al-Hujwīī, The Kashf al-Mahjûb-The Oldest Persian Treatise on Sufism, trans. R.A. Nicholson (London 1970), pp. 167-168; Al-Ghazzzālī-al-Subkī, Tabaqāt alShāfi iyya al-Kubrā, vol. 6, p. 247. See also H. Lazarus-Yafeh, Studies in Al-Ghazzāli (Jerusalem 1975), p. 531; Kubrā—see Najm al-Dīn Kubrā, Fawāịh al-Jamāl wa-Fawātị̣ al-Jalāl, ed. Yusūf Zaydān (Kuwayt, 1993), p. 48, and see also 'Abd 
may also explain why writings by others were ascribed to him in the course of time, a rather common pattern during the Middle Ages. ${ }^{9}$

\section{On the Question of the Erroneous Ascription}

In the introduction to his edition of the Tartib, Meier raises several puzzling issues about it: the work does not feature in pre-fourteenth century literature; the few biographical details noted in it do not appear in al-Qushayrī's biographies; Al-Qushayrī's teacher, Abū 'Ali al-Daqqāq, is not mentioned in the Tartīb; Al-Subkī, the author of Tabaqāt al-Shāfi iyya, does not count it among al-Qushayrī's works; the linguistic style of the work differs al-Qushayrì's usual style; the description of the fasting ritual in the Tartīb is different from that in al-Qushayrì's Risāla. Meier nevertheless ascribes the work to al-Qushayrī. He tries to settle the language problem by claiming that the text was recorded by a disciple, and suggests that some of the difficulties should be understood as part of the problems that emerged in the manuscripts. Concerning the biographical questions, he offers unproven hypothese. As for Al-Daqqāq's absence from the treatise and the issue of the fast, he admits he has no answers. ${ }^{10}$

In this article, I will show that the Tartīb presents views antithetical to those of al-Qushayrī. My findings rest on a comparison between the Tartīb and four other works, whose ascription to al-Qushayrī is accepted:Al-Risāla al-qushayriyya fi 'ilm al-tașawwuf, his most famous work;' Lațā'ifal-'ishārāt

al-Karim Al-Qušayri, Das Sendschreiben Al-Qušayrīs über das Sufitum, eingeleitet, übersetzt und kommentiert von R. Gramlich, p. 17; Ibn al-'Arabi relates that he read the Risāla at the beginning of his mystical path-see S. Sviri, "Review of al-Qushayrī, Principles of Sufism, trans. B.R. Von Schlegell, introduction: H. Algar, Berkeley 1990", Jerusalem Studies in Arabic and Islam 19 (1995), p. 272. For Rūmī as well as for al-Hujwīrī, al-Ghazzāli, 'Ațțār and Ankaravi see Algar's introduction to al-Qushayrī, Principles of Sufism, trans. B.R. Von Schlegell, introduction: H. Algar, pp. xii-xiv. Al-Qushayrî's influence on the development of Sufi Literature in Morocco is mentioned in D. Ephrat, "In Quest of an Ideal Type of Saint: Some Observations on the First Generation Of Moroccan Awliyā' Allāh in Kitāb al-tashawwuf", Studia Islamica 94-95 (2002), p. 68.

9 H. Lazarus-Yafeh, Studies in Al-Ghazzali, pp. 256-257.

10 F. Meier, "Qušayrī's Tartīb As-sulūk", pp. 7-10.

11 'Abd l-Karīm b. Hawāzin al-Qushayrī, al-Risāla al-qushayriyya fì 'ilm al-tașawwuf, ed. Khalīl al-Munșiq (Beirut, 1998). The Risāla includes a short chapter describing the concepts of faith endorsed by the great sufi masters (pp. 11-20). 
(henceforth Lațā'if ), his extensive Sufi-Ash'ari commentary on the Qur'ān:; ${ }^{12}$ Al-Tahbir fi al-Tadhkir (henceforth Tahbir), a discussion of God's holy names; ${ }^{13}$ and Kitāb al-Miriāj (henceforth Mi'rāj), dealing with the story of Muhammad's ascension to heaven on the night of al-'Isrä' wa-al-Mi'rāj. ${ }^{14}$ The gaps between these four works and the Tartīb are irreconcilable.

These concepts accord with 'ash'arite theology. An extensive chapter is devoted to eighty-three celebrated Sufis (pp. 21-88). Another chapter explains common terms in Sufi literature (pp. 89-125). Fifty-one relatively brief chapters discuss topics and terms central in Sufi life and in the mystical path. At the end of this work is a chapter entitled al-Wașiyya li-al-Murìdin, including practical guidance for those wishing to follow the Sufi way (pp. 413-436). For some examples of the Risāla's fame in Muslim literature see: 'abd al-Karīm b. Muhammad al-Rāfic al-Qazwin̄ì, al-Tadwìn fì 'akhbār al-Qazwīn, ed. Alshaykh 'azīz Allāh al-'Aț̣āridī (Beirut, 1987), vol. 3, p. 11; al-Subkī, Țabaqāt al-Shāfíiyya al-Kubrā, vol. 5, p. 153; Abū al-'Abbās 'Aḥmad b. Khalikān, Wafayāt al-'ayyān wa-'anbā' 'abnā' al-zamān, ed. 'Iḥsān 'Abbās (Cairo, 1977), vol. 3, p. 206; 'Abd al-Hayy b. 'Aḥmad b. 'Imād, Shadharāt al-Dhahab fi' 'Akhbār man Dhahab, ed. 'Abd al-Qādir al-'Arnā'ūt (Damascus, 1989), vol. 5, pp. 275-276. Both Arberry and Gramlich regard the Risāla as the most famous and widespread work in the history of Sufism-A.J. Arberry, Sufism, pp. 28, 71; 'Abd al-Karim Al-Qušayri, Das Sendschreiben Al-Qušayrīs über das Sufitum, eingeleitet, übersetzt und kommentiert von R. Gramlich, p. 10. For a detailed description and analysis of the Risāla, its contents and several of its editions and translations, see: E. Stern, Protection From Sin in al-Qushayrì's Thought, pp. 64-76.

12 'Abd l-Karīm b. Hawāzin al-Qushayrī, Lațā'if al-'ishārāt-tafsīr șūfı̀ kāmil li-alQur'ān al-karìm, ed. 'Ibrāhīm Basyūnī (Egypt, 1983), 3 vols. Every verse or group of verses is followed by commentary. The work includes a range of exegeses common in traditional Sunite interpretations of the Qur'ān, as well as a mystical and theological interpretive layers. For a detailed description and analysis of the Lațāif, its history, contents and interpretation layaers, as well as a discussion of its editions, see: E. Stern, Protection From Sin in al-Qushayrìs Thought, pp. 76-84. see also: A. Keeler, "Șūfì tafsīr as a Mirror: al-Qushayrī the murshid in his Lațāiif al-ishārāt", Journal of Qur'anic Studies 8 (2006), pp. 1-21.

13 'Abd l-Karīm b. Hawāzin al-Qushayrī, Al-Tahbīrfial-Tadhkīr-dirāsa li-'asmā' Allāh al-Husnā wa șifātihi bi-qalam bāhith șūfì wa-sunnī 'Ash'arī, ed. 'Ibrāhīm Basyūnī (Cairo, 1968). This work contains commentaries and explanations of God's names, as well as spiritual and ethical aspects that can be learned from their study. See: E. Stern, Protection From Sin in al-Qushayrī's Thought, pp. 85-86.

14 'Abd l-Karīm b. Hawāzin al-Qushayrī, Kitāb al-Mi'rāje, ed. 'Ali Hasan 'Abd al-Qādir (Cairo, 1964). The treatise discusses traditions of Hadīth and Qur'ānic verses dealing with al-'Isrä's wa-al-Mi'räj, the night journey of the prophet and his ascension to heaven. It also discusses the link between the Miräj experience of the prophets and the experience of the Sufis. See: Q. Samarrai, The Theme of Ascension in Mystical Writings, pp. 183-265. See also my discussion of the treatise-E. Stern, Protection From Sin in al-Qushayri’s Thought, pp. 88-89. This discussion includes 
Stylistic variations are considerable, and there are also differences in content and outlook and at times actual contradictions, often on very crucial points. The teacher of the Tartīb's author is not al-Qushayri's teacher. Furthermore, the Tartīb presents a view unlike that of al-Qushayrī as to who is altogether worthy of being a teacher; the mystical path according to the Tartīb is not that described by al-Qushayrī. The dhikr, the observance of the Shari ${ }^{-} a$ commandments, and the figure of Satan as described in the Tartīb are also inconsistent with al-Qushayri's views. These last three issues contradict al-Qushayri's rigorously nomistic and Ash'arite views, which demand meticulous and uncompromising observance of the commandments and the acknowledgement of God as the sole and single entity determining everything that happens in all creation, including every aspect of all forms of mystical experiences. The conclusion, then, is that the Tartib's author and al-Qushayrī are two different people representing different trends within Sufism. ${ }^{15}$

a comparison between al-Qushayrì's views regarding the Mírāj and the views of some other authors.

15 Al-Samarrai holds that al-Qushayrī wrote the Tartīb when beginning his studies, before becoming fully versed in Sufi language and terminologyQ. al-Samarrai, The Theme of Ascension in Mystical Writings, p. 46. This is an unacceptable claim, since the Tartīb's author attests he has already reached the summit of the mystical path (see below p. 23). Furthermore, al-Qushayrī embarked on his Sufi path after becoming widely learned in various realms of knowledge. On his rich education as a child and a youth see: al-Qazwīnī, al-Tadwìn fì 'akhbār al-Qazwìn, vol. 3, pp. 210-211; Ibn Khalikān, Wafayāt al-'ayā̄n wa-'anbā' 'abnā' al-zamān, pp. 205-206; Ibn 'Imād, Shadharāt al-Dhahab fi' 'akhbār man Dhahab, vol. 5, pp. 277; Q. al-Samarrai, The Theme of Ascension in Mystical Writings, pp. 32-34; E. Stern, Protection From Sin in al-Qushayr's Thought, pp. 11-12, 41-43. The language of the Tartīb, if al-Qushayrī was indeed its author, would have attested to his erudition, and this is not the case. A large gap is discernible between the language and literary level of al-Qushayrī's treatises and those of the Tartīb. In al-Qushayrîs treatises, the language is flowery, rich in puns and sophisticated metaphors. The linguistic gulf between them and the Tartīb is comparable to that between the register of high literary today and the spoken language used, for instance, in the media or perhaps even slang. The special poetics of al-Qushayri's writings is the subject of a chapter in my PhD dissertation-E. Stern, Protection From Sin in al-Qushayrìs Thought, pp. 94-126. 


\section{The Dhikr in the Tartīb al-Sulük}

Before we proceed to the actual comparison, there is room for a succinct description of the Tartib's central content - the dhikr.

Tartīb al-Sulūk is a brief, nine-chapter treatise devoted to the dhikr, a ritual in which the Sufi focuses his consciousness solely on the ceaseless memorizing and remembrance of God's name until reaching an ecstatic experience. ${ }^{16}$

The dhikr is the core of the mystical path in the Tartïb, from its beginning, when he who embarks on it takes his first steps, until its end, when he experiences feelings of selfobliteration and unio mystica. Following are its main stages:

Preparing for the dhikr. The person wishing to pursue a mystical path will renounce all possessions, will observe the commandments of Islam, and will be meticulous about the impeccable purity of his body and attire. Having passed this test, he will find a teacher willing to guide him in the mystical way.

The disciple will then assume an ascetic way of life, living in poverty and humility. He will avoid all unnecessary speech and refrain from eating. Of the Islamic commandments, he will observe those accepted as compulsory, as well as two rak'as of the al-Duha prayer (a known discretionary prayer, usually performed in the morning) and two rak'as performed after every short purification ritual $\left(w u d \bar{u}^{\prime}\right) \cdot{ }^{17}$ Except for these, he is not to observe any other supererogatory commandments (nawäfl), not even the reading of

16 Much has been written in the research literature about the dhikr. See, for instance, L. Gardet, "dhikr", EI², 2 (1965), pp. 223-227; S. Sviri, The Taste of Hidden Things, (Inverness, 1997), pp. 124-144. For a psychological emotional explanation of states of consciousness in the course of the mystical path, see pp. 23-45; M.I. Waley, "Contemplative Disciplines in Early Persian Sufism", in L. Lewisohn, Classical Persian Sufism from Its Origins to Rumi (London and New York, 1993), pp. 497-548; H. Algar, "Silent and vocal dhikr in the Naqshbandi order", Akten des VII Kongresses für Arabistik und Islamwissenschaft, ed. A. Dietrich (Göttingen, 1976), pp. 39-46. On Islam-Judaism links concerning the dhikr, see Paul Fentom (Yosef Yinon), "Rosh beyn ha-Birkayim" (Head between the Knees-in Hebrew), Daat-A Journal of Jewish Philosophy \& Kabbalah, 32-33 (1994), pp. 19-29.

17 On the importance of purity, see A. Schimmel, Mystical Dimensions of Islam, pp. 148-149. On the practice of performing two rak'as after purification as part of the dhikr ritual, see A.J. Arberry, Sufism, An account of the mystics of Islam, (London, 1950), p. 130. 
the Qur'ān. After meeting these conditions, he will concentrate his full attention only on God and begin the dhikr.

The dhikr includes three main stages: (1) Dhikr al-lisān-which is performed vocally and aloud; (2) Dhikr al-qalb — which is performed silently in one's heart (qalb), the center of the person's mystical being; (3) Dhikr al-sirr - the dhikr of the inner secret. The sirr is a hidden deep spiritual point inside the heart, where the mystical experience is even purer than that of the heart itself.

Dhikr al-lisān. ${ }^{18}$ This dhikr, which begins with the articulation of the usual formula Allāh Alläh can continue for years. It involves the articulation of words in which body limbs also participate through a weak sense of movement within them. Two processes of exaltation are experienced in its course. In the first process, the dhikr performer experiences two contradictory mystical states: ghayba (absence), a kind of self-forgetfulness, and hudūr (presence), a return to wakeful self-consciousness. ${ }^{19}$ Both these states are recurrently repeated, and at the end of every repetition the person senses he has reached a higher mystical level.

In the second process of exaltation, the dhikr performer experiences a sense of infinite growth, which ceases when an urgent sense of fear (qahr min al-khawf) forces him to stop growing, and all is then repeated anew. At the height of the process, the dhikr performer experiences a wurüd (a mystical revelation). He feels $f a n \bar{a}^{\prime}$ (annihilation), and afterwards experiences $b a q \bar{a}^{\prime}$ (subssistence [in God]), ${ }^{20}$ a sense of being that is experienced as if taking place within the deity. The physical senses are dimmed and the dhikr shifts, as if on its own, to the heart.

Dhikr al-qalb. ${ }^{21}$ The dhikr now takes place in silence, within the mystic's heart. He is affected by intense physical and emotional experiences. His

18 F. Meier, "Qušayrī's Tartīb As-sulūk", pp. 16, 18-20.

19 Compare with al-Qushayrī's explanation, whereby ghayba is a state in which a person becomes unaware of his surroundings or of his own feelings, whereas the term hudūr can be explained either as the presence of God that is experienced during the ghayba or as the opposite of the ghayba, implying the person returns from the ghayba to awareness of his surroundings (al-Qushayrī, Risāla, al-ghayba wa-al-hudūr, pp. 104-106).

20 Definition given by Alexander D. Knysh, al-Qushayrī's Epistle on Sufismal-Risāla al-qushayriyya fì 'ilmal-tașawwuf(UK, 2007), p. vii. Annemarie Schimmel's definition of the term baqā is: "remaining" in God after annihilation, eternal life. See her Mystical Dimensions of Islam, p. 498.

21 F. Meier, "Qušayrī's Tartīb As-sulūk", pp. 16-21, 27. 
senses cease to function, and all in the created world is heard and seen in his heart through the force of a special light. His body movements are no longer controlled by his own powers but by that of a mystical inspiration $($ wurūd). He may also sense a sweetness in his mouth, so strong that he fears it may kill him. He then finds it hard to open his mouth, sensing it is full of food or drink emanating from the roots of his teeth. He may also feel unable to sleep, sometimes even for years. ${ }^{22}$ Exaltation is also part of the dhikral-qalb. Experiences of $f a n \bar{a}^{\prime}$ and $b a q \bar{a}^{\prime}$ recur one after another, and at the end of each such pair the performer reaches a higher level.

The dhikr intensifies. The dhikr performer feels how all his limbs increasingly recite the dhikr together with his heart-first only with energetic moves and finally through voices and words. The heart becomes the source of dhikr formulations ('adhkār) and of divine names ('asmä', tasmiyāt) in increasing numbers. They are revealed in an infinite number of languages and in different expressions ( $i b \bar{a} r a \bar{t}$ ), all previously unknown to any man or even to an angel. The dhikr increasingly rises until the man imagines this is an actual physical voice that others also hear. The entire creation appears to him as if engaged in performing various forms of dhikr until, finally, he is no longer able to distinguish between his dhikr and that of creation. A mystical revelation then descends upon him, which shifts the dhikr to the inner secret in the heart-al-sirr.

Dhikr al-sirr. ${ }^{23}$ At this stage, the sirr al-ghayb (the secret of the unseen) is revealed, the most sublime mystical experience. The mystic no longer experiences any feeling, or even any consciousness of human existence. The mystical states previously surging in his heart now cease. The senses are now numb and there is no movement. All that remains is a consciousness of God. At first, a kind of vague consciousness still prevailed that contemplates from a distance, as if in a dream, the dialogue sometimes taking place between God and alsirr, but the distinction finally melts and any consciousness of duality fades. This peak is the jam 'al-jam' (the union of the union), and is characterized by the mahw al-'ashkhās (the obliteration of human beings), namely, the erasure of their separate consciousness. ${ }^{24}$

22 Lack of sleep is only typical of the sweetness stage. At other stages of the $d h i k r$, and particularly at the beginning, the author invests great efforts in trying to avoid the sleep engulfing him-F. Meier, "Qušayrì's Tartīb As-sulūk", pp. 21, 26.

23 F. Meier, "Qušayrī's Tartīb As-sulūk", pp. 17, 21-22, 27, 28.

24 In the treatise (F. Meier, "Qušayrī's Tartīb As-sulūk", p. 22), we are told that this is the stage at which Abū Yazīd (Al-Bisțāmī, d, 261/875?) and Abū Manșūr al-Hallāj (d. 309/922), who is not mentioned by name, called out their famous 


\section{The Tartīb and al-Qushayrī's Four Treatises: Comparing Contents}

\section{The Description of the Mystic Way}

The Tartīb's description of the mystic way differs from that in al-Qushayrì's four works. Most of the mystical terms al-Qushayrī uses in his works, including some of the most prominent, are not to be found in the Tartīb. The ones that do appear in the Tartīb are those common in the literature, and cannot be ascribed to a specific author. Their mention in a kind of glossary chapter, which al-Qushayrī devotes in the Risāla to the description of terms common among the Sufis ('alfāz tadūru bayna hādhihi al-țà' ifa), actually attests to this. ${ }^{25}$ At the same time, the glossary also attests to the inadequacy of the Tartīb, which lacks more than half of the terms found in the glossary chapter. The description of the various stages in the mystic way and their order, as well as that of the mystics' ranks, is different in the Tartīb and in al-Qushayrī's treatises.

A full description of the mystic way and its stages as described in al-Qushayrī's oeuvre exceeds the scope of the paper. The treatises are not one of a kind. Their different themes, the many sources cited, the extremely personal and amorphous nature of the mystical experience, the florid and emotional language-all lead to various concepts sometimes being used

ecstatic cries (shațahāt or shaṭhiyyāt) —: subhān̄i ("May I be praised"-Al-Bisțāmī) and 'anā al-ḥaqq ("I am the truth", meaning I am God-Al-Hallāj). These two calls are the most famous in the shațahāt uttered by Sufis. See Louis Massignon, The Passion of al-Hallāj-Mystic and Martyr of Islam, abridged edition. Translated from the French and edited by Herbert Mason (New Jersey, 1982), pp. 64-71; L. Massignon, Essay on the origins of the technical language of Islamic mysticism, translated from the French by Benjamin Clark (Notre Dame, Ind, 1997), pp. 28, 191192; R.A. Nicholson, The Mystics of Islam (London and Boston, 1914), pp. 149-153; A. Schimmel, Mystical Dimensions of Islam, pp. 64, 145. See also 'Ahmad Sirhindī's (d. 1034/1624) attitude to these two calls: Y. Friedmann, Shaykh Ahmad SirhindiAn Outline of his Thought and a Study of His Image in the Eyes of Posterity (New Delhi, 1971), pp. 28, 60-61, 63, 65. The saying of shathiyyāt was ascribed to Sirhindī himself (p. 95). For a discussion of such cries, see C.W. Ernst, Words of Ecstasy in Sufism (Albany, 1985); 'Abd al-Raḥmān Badawī, Shațahāt al-Ṣūfiyya-al-juz' al-'awwal: Abū Yazìd al-Bisțāmī (Cairo, 1949).

25 Al-Qushayrī, Risāla, pp. 89-125. Among the terms appearing in the Tartīb: al-maqām, al-hầl, al-hayba, al-fanā'wa-al-baq $\bar{a}$, al-ghayba wa-al-hudūr (F. Meier, "Qušayrī's Tartīb As-sulūk", pp. 16-18), al-sirr (pp. 17, 21-22), al-maḥw, jam 'al-jam', al-khawāțir, al-wārid (pp. 22-23), al-'uns (p. 24), al-basț (p. 26). 
alternatively. ${ }^{26}$ Nevertheless, there are certain modes of discussion and key Sufi terms that characterize al-Qushayrī. The Tartīb lacks most of them. Some of these concepts serve, in a way, as standard "technical terms" for describing mystic matters. In the Risāla, al-Qushayrī even seeks to clarify this terminology for those who follow the Sufi way. ${ }^{27}$ It can hardly be assumed that in a discussion of the mystic path from its initial stages and up to its summit, as that found in the Tartīb, al-Qushayrī would refrain from using a terminology that he himself worked so hard to teach. In one or another work or before different audiences, al-Qushayrī could obviously omit some of the many concepts of which I will only cite a few; the absence of many important terms and concepts, however, can strongly attest that al-Qushayrī is not the Tartīb's author.

\section{Discussing mystical states}

Al-Qushayri often describes mystical states in pairs, triads, and at times even in quartets, describing relationships of opposition, complementarity, or ascension from one state to another. Most prominent are pairs of mutually opposed states that the mystic experiences at one or more stages of his mystical path. His consciousness then oscillates between two states-at

26 One instance is al-Qushayrī's use of the known pair of terms maqām (generally described as a mystical rung perceived as reached through man's own efforts) and $h \bar{a} l$ (a mystical state bestowed on man through God's grace). See Al-Qushayrì's explanation of these two terms in the glossary chapter-Risāla, pp. 91-93. Later in the Risāla al-Qushayrī tells us that the Iraqi and Khurasani Sufi schools were divided concerning the rid̄a (level of contentment), as to whether it is maqām, as in the Iraqi version, or perhaps $h \bar{a} l$, as in the Khurasani version. Al-Qushayrī suggests a kind of compromise: the beginning of the rida is maqām, but its end can only be attained through a divine gift of hầl. See al-Qushayrī, p. 228 (Risāla, bāb al-rị̂a $)$. This example appears also in R. Hartman, Al-Kuschairîs Darstellung des Sûfitums, p. 21; A.J. Arberry, Sufism, An account of the mystics of Islam, p. 77; and F. Meier, Abū Sa'ì-I Abū l-Hayr (357-440/967-1049), Wirklichkeit und Legende, pp. 4-5. On al-Qushayrī role as a mediator between these two schools see: J. Chabbi, Remarques sur le développement historique des mouvements ascétiques et mistiques au Khurasan, pp. 31-32, 41, 63-65, 69-70; A. 'Afifi, al-Malāmatiyya wa-al-Șūfiyya wa-'ahl al-Futuwwa, pp. 19, 42, 49-52; S. Sviri, "Review of al-Qushayrī, Principles of Sufism, trans. B.R. Von Schlegell, introduction: Hamid Algar, Berkeley 1990", Jerusalem Studies in Arabic and Islam 19 (1995), pp. 272-275; C. Melchert, "Sufi and Competing Movements in Nishapur, pp. 239-240; E. Stern, Protection From Sin in al-Qushayrï's Thought, pp. 18-35, 68-73.

27 See his introduction to the Risāla-al-Qushayrī, Risāla, pp. 8-9, and see also the beginning of the glossary chapter-p. 89 . 
one time he is in one of them, and at another in its opposite. About half of the mystical states described in the glossary chapter of the Risāla, over twenty of them, are arranged in such pairs. ${ }^{28}$ Only two pairs of mystical states are noted in the Tartīb, (ghayba and hudūr; fan $\bar{a}^{\prime}$ and $\left.b a q \bar{a}^{\prime}\right)$, and there are no triads or quartets.

\section{The absence of crucial mystical states}

Two states describing the peaks of the mystical way, common in Sufi literature in general and in al-Qushayrī's writings in particular, are glaringly absent in the Tartīb: Al-yaqin (mystical certainty) and al-mahabba (mystical love). The yaqin is discussed in the glossary chapter of the Risāla, as well

28 For instance: al-sahw and al-sukr (mystic sobriety and ecstasy), see al-Qushayrī, Risāla, pp. 106-108; al-Qushayrī, Lațā̉if, vol. 3, p. 93. Al-qabḍ and al-bast (constraction and expansion) — at times the Sufi is entirely desolate and at times he is in a state of ease, relief and joy. See al-Qushayrī, Risāla, pp. 93-95; al-Qushayrī, Lațäif, vol. 3, pp. 63, 93, 339-340. On the ubiquitousness of the pair, see A. Schimmel, Mystical Dimensions of Islam, pp. 128-129. Jam' and farq (experiences of union with a divine reality and detachment from it), see al-Qushayrī, Risāla, pp. 100-101. We sometimes find psychological explanations for the ascension from one state to another. For instance, the mystic reaches the states of al-qabd and al-bast after passing through states of al-khawf (fear) and al-rajä' (hope). Al-Qushayrī (Risāla, pp. 93) explains that when the mystic is in a state of al-khawf and al-raja $\bar{a}^{\text {, }}$ he focuses on the future-fearing disaster or hoping for fortune (perhaps fearing God might reject him and hoping He will accept him). Later, in states of al-qabḍ and al-bast, he focuses on the present, on his immediate experience.

On the contrasting states in Sufi literature, see S. Sviri, "Between fear and hopeon the coincidence of opposites in Islamic mysticism", Jerusalem Studies in Arabic and Islam, 9 (1987), pp. 316-349. Examples of mystical states in triads: some rungs are bidāya (the beginning stage in the mystical way), others are wäsita (the middle of the mystical way), and others are nihāya (the end, completing the mystical way and reaching its summit). This is also the case, for instance, concerning al-tawakkul (al-bidāya), al-taslīm (al-wāsița) and al-tafwì̄ (al-nihāya)-three successive rungs expressing trust in God and wholehearted and unswerving devotenesssee al-Qushayrī, Risāla, pp. 203-204 (bāb al-tawakkul). Another complex example (pp. 111-112): three states of consciousness in which the mystical reality is revealed to the mystic: al-muhâdara (the presence attesting to the mystical reality), al-mukāshafa (the discovery of the mystical truth) and al-mushāhada (the vision of the mystical truth). Attached to each of these three types of consciousness is one of three types of knowledge: 'aql (understanding), 'ilm (mystical knowledge), ma'rifa (gnostic enlightenment, experiential mystical awareness). Further instances: pp. 96-10o, 112-113, 121, 233. See also my detailed discussion: E. Stern, Protection From Sin in al-Qushayrì's Thought, pp. 105-107. 
as in a separate chapter devoted to it. ${ }^{29} \mathrm{~A}$ special chapter in the Risāla is also devoted to the mahabba, which is sometimes tied to the dhikr and to the himma (a spiritual faculty related to the concentration of consciousness, important concepts in the Tartīb). ${ }^{30}$ al-Qushayrī would most probably not describe the peaks of mystical experience without recourse to these two terms.

\section{Differences concerning the person's spiritual structure}

Knowledge of this structure is imperative for describing the mystical experience. Al-Qushayrī postulates three mystical "limbs": al-qalb (the heart), al-sirr (the inner secret), both of which we have already encountered in the Tartīb, and al-rūh (the spirit), the breath of life that God breathed into human beings, also a place for an experience of mystical exaltation. The rūh is an item in the Risāla's glossary chapter. ${ }^{31}$ It is not mentioned in the Tartīb.

More important is the Tartīb's failure to refer to the nafs (the lower soul), the location of the passions and lusts, to which the Risäla also devotes an entire chapter and an entry in the glossary. ${ }^{32}$ This is the enemy calling human beings to follow their passions. The danger of the hawäjis al-nafs (the lower soul's call to follow the passions) is no less perilous than the menace of waswās (a term usually indicating Satan's whispers). ${ }^{33}$

29 Al-Qushayrī, Risāla,pp. 121, 214-218. Theyaqīn has various levels, also arranged in triads: 'ilm al-yaqin (the knowledge of the mystical certainty); 'ayn al-yaqin (the essence of certainty), haqq al-yaqin (the truth of certainty).

30 Al-Qushayrī, Risāla, pp. 247-257. See a detailed description of the mahabba in the Lațä'if, vol. 1, pp. 431-432. In this description, al-Qushayrī links the mahabba to the dhikr and the himma. See also vol. 3, pp. 140, 313, 403.

31 Al-Qushayrī, Risāla, p. 124; al-Qushayrī, Taḩbìr, p. 25, note 3. A hint at the dhikr: the tongue, the heart, the spirit, and the inner secret, all recite Allāh's name simultaneously. See al-Qushayrī, Lațāifi, vol. 1, pp. 217-218, 528; vol. 3, pp. 63, 284, 641; al-Qushayrī, Mírāj, p. 107.

32 Al-Qushayrī, Risāla, pp. 188-192 (Bāb mukhālafat al-nafs wa-dhikr 'uyūbihā), and p. 123 .

33 Al-Qushayrī, Risāla, pp. 103 (glossary chapter: al-fanā' wa-al-baqā'), 119120 (glossary chapter: al-nafs; al-khawāțir), 292-293 (bāb al-wilāya); al-Qushayrī, Latā'if, vol. 3, p. 788. On the saying 'aș'ab al-shayātitin nafsuka (the harshest of Satans is your lower soul) see vol. 3, p. 367. On the struggle with the passions in the Wașiyya chapter, see al-Qushayrī, Risāla, pp. 431-434. In the glossary chapter see pp. 119-120 on the distinction between the hawäjis and the waswās. See also al-Qushayrī, $L a t \bar{a}^{\prime}$ 'if, vol. 1, p. 528. For some research studies of the nafs and the fight against its perils see: A. 'Afîfī, al-Malāmatiyya wa al-Șüfiyya wa-'Ahl al-Futuwwa, 


\section{No allusion to mystical ranks}

Except for the common term 'ahl al-nihāya (those reaching the final stage), the Tartīb does not allude to mystical ranks. ${ }^{34}$ By contrast, al-Qushayrī often provides names and descriptions of Sufis in general and of the mystical ranks, which describe levels of mystical attainment. People at various mystic ranks are often cited in pairs, triads, and quartets, such as the mutasākir, the sakrān, and the Șạhin - the first two having reached ecstasy ranks, the second higher than the first, and the third at a level of sobriety reflecting an intensified mystical experience. This is the sobriety of a person whose consciousness has merged into God's, and thus ranks higher than the ecstasy. ${ }^{35}$ Two ranks are glaringly absent from the Tartib: al-murid (the novice) and the waliyy ('awliy $\bar{a}$ ' in plural — the Sufi holy man, the friend of God). The murid is the subject of two chapters in the Risāla, of which the Wașiyya li-al-muridin (guidance to novices on the Sufi way-henceforth Wașiyya) is the most significant. ${ }^{36}$ The absence of the term murid from the

pp. 49-68; E. Kohlberg's introduction in: Abū 'Abd al-Raḥmān al-Sulamī, Jawāmi' 'Ā dāb al-Șūfiyya wa-'Uyūb al-Nafs wa-Mudāwātuhā, ed. E. Kohlberg (Jerusalem, 1976), pp. 14-18; S. Sviri, "Hakīm Tirmidhī and the Malāmatī Movement in Early Sufism”, in L. Lewisohn (ed.), Classical Persian Sufism: From Its Origins to Rumi (New York, 1993), pp. 596-599, 6o6-613; S. Sviri, "The Self and Its Transformation in Süfism-With Special Reference to Early Literature", in D. Shulman and G.G. Stroumsa (eds.), Selfand Self-transformation in the History of Religions, Oxford, 2002; E. Stern, Protection From Sin in al-Qushayri’s Thought, pp. 27-30.

34 For 'ahl al-nihāya, see F. Meier, "Qušayrī's Tartīb As-sulūk", p. 21. Only some of the general terms are mentioned: 'abd (slave)—p. 15 and throughout; 'ustādh (mentor)-pp. 15-16, 21; șāhib hädhihi al-'aḥwāl (he who is experiencing such mystical states) - p. 21; Fuqarä' (the poor)—p. 15; Qawm (people)—p. 26.

35 Al-Qushayrī, Risāla, p. 108. Examples of general Sufi descriptions that appear hundreds of times in al-Qushayrī's works: 'Awāmm (ordinary folk), khawāṣs (the privileged few, with knowledge of the arcane), and khawāṣ al-khawāṣs (the most sublime). For examples of several triads parallel to this one, see al-Qushayrī, Lațā'if, vol. 2, pp. 90-91. On the concept of khawāsss, see also Lazarus-Yafeh, Studies in Al-Ghazzāli, pp. 349, 351; Y. Friedmann, Shaykh Ahmad Sirhindi-An Outline of his Thought and a Study of His Image in the Eyes of Posterity, pp. 26, 50. For additional instances of triads, see al-Qushayrī, Risāla, pp. 43, 94; al-Qushayrī, Lațā'if, vol. 1, p. 253. For additional instances of levels of prominence, see 'ahl al-tahqīq in vol. 1, p. 253 and in al-Qushayrī, Mírāj, p. 94; see also 'ahl al-tarīqa in al-Qushayrī, Lațā'if, vol. 1, p. 258; in p. 306 see Zāhidūn, 'ābidūn, 'ārifün; and in vol. 3, p. 111, see 'ahl al-wuṣla wa'ahl al-furqa.

36 Al-Qushayrī, Risāla, pp. 235-239 ( bāb al-'irāda), 424-436 (bāb al-wașiyya li-almurìdin ). A certain type of guidance literature for novices in the Sufi way resorts to the murìd concept quite frequently. See, for instance, Abū al-Najīb al-Suhrawardī, 
Tartīb is particularly odd, since this treatise is also meant to provide guidance to followers in the Sufi way.

The 'awliy $\bar{a}$ ', the friends of God, are recurrently noted in Sufi literature. Karāmāt (wondrous miracles) are sometimes ascribed to them. Al-Qushayrī refers to them in all his works and devotes two chapters of the Risāla to them..$^{37}$

The Tartīb intimates that the karāmāt are a type of wondrous events that happened to the author in his sleep, apparently before completing his mystical course, but the concept waliyy is not mentioned. ${ }^{38}$

\section{The Teacher of the Tartīb's Author and the Teaching Question}

The teacher of the Tartīb's author is not al-Qushayrìs teacher

Al-Qushayrī's leading teacher and his guide in the mystic way was Abū 'Ali al-Daqqāq (d. 405/1015 or 406/1016 or 412/1021 or 420/1029). ${ }^{39}$ From his nicknames and his utterances as cited in the Risāla, he clearly emerges as the main source of al-Qushayrī's mystical thought. His name is noted not only in the Risāla. ${ }^{40}$ By contrast, the teacher of the Tartīb's author, although his

Kitāb 'Ādāb al-Murìdīn, ed. M. Milson (Jerusalem, 1977); M. Milson (trans), A Sufi Rule for Novices-Kitāb 'Àdāb al-Murīdīn of Abū al-Najīb al-Suhrawardī (Cambridge, 1975).

37 Al-Qushayrī, Risāla, pp. 292-295 (bāb al-wilāya), pp. 378-413 (bāb karāmāt al-'awliy $\bar{a}^{\prime}$ ); for a discussion of the himma of the 'awliya ', see al-Qushayrī, Lața' 'if, vol. 1, p. 151. See also in p. 239 a brief example of a discussion of karāmāt al-' awliy $\bar{a}$.

38 F. Meier, "Qušayrī's Tartīb As-sulūk", p. 26.

39 J. Chabbi, "Abū 'Alī Daqqāq", Encyclopaedia Iranica 1 (1985), pp. 255-257; Ibn Khalikān, Wafayāt al-'a yān wa-'anbā' 'abnā' al-zamān. vol. 3, p. 208; Q. Samarrai, The Theme of Ascension in Mystical Writings, p. 35; 'Abd al-Karim Al-Qušayri, Das Sendschreiben Al-Qušayrīs über das Sufitum, eingeleitet, übersetzt und kommentiert von R. Gramlich, p. 11; J.A. Mojaddedi, The Biographical Tradition in SufismThe Țabaqāt Genre from al-Sulamì to Jāmī (Surrey, 2001), p. 100.

40 For instance, al-Qushayrī, Taḥbìr, p. 52; al-Qushayrī, Mírāj, p. 68. Al-Qushayrī studied with many teachers. Among his Sufi mentors, we know for example of 'Abd al-Rahmmān al-Sulamī (d. 412/1021). He heads many of the chains of transmitters of Sufi traditions that appear in the Risāla. On his importance for the study of al-Qushayrī's sources, see J.A. Mojaddedi, “Legitimizing sufism in al-Qushayrī's Risāla", pp. 37-50. See also Ibn 'Asākir, Tabyīn kidhb al-muftarī fìmā nusiba 'ilā al-'Imām al-'ash'arī, p. 273; A. 'Afîfī, al-Malāmatiyya wa-al-Șūfiyya wa-'Ahl alFutuwwa, pp. 74-76, 79; Q. al-Samarrai, The Theme of Ascension in Mystical Writings, p. 35; R.W. Bulliet, The Patricians of Nishapur, p. 152; 'Abd al-Karim Al-Qušayri, Das Sendschreiben Al-Qušayrīs über das Sufitum, eingeleitet, übersetzt und 
name is not explicitly mentioned, is Abu al-Hasan. ${ }^{41}$ We learn this from the fact that he is the one who identifies the author's mystical state when the dhikr intensifies, and he is the one who teaches him the special dhikr formula and its mode of articulation, which bring the author to the dhikr alsirr, the peak of the mystical way. ${ }^{42}$

At the beginning of the Tartīb we learn that the ability to discern developments unfolding in the disciple's heart and teaching him dhikr formulae are among the skills required from teachers. ${ }^{43}$ In the Risāla, al-Qushayrī more explicitly describes knowledge of developments in the disciple's heart and the teaching of the dhikr as incumbent on the teacher. The Wașiyya

kommentiert von R. Gramlich, p. 12; E. Stern, Protection From Sin in al-Qushayrìs Thought, pp. 43-45. The sources and scholarly research, however, unquestionably identify al-Daqqāq as al-Qushayrī's main mentor and his guide in the Sufi way. See, for instance, Ibn 'Asākir, Tabyīn kidhb al-muftarīfimā nusiba 'ilā al-'Imām al-'ash'arī, p. 274; al-Qazwīnī, al-Tadwìn fì 'akhbār al-Qazwīn, vol. 3, p. 211; Ibn Khalikān, Wafayāt al-'ayyān wa-'anbä' 'abnā' al-zamān, p. 206; Ibn 'imād, Shadharāt al-Dhahab fi' 'akhbār man Dhahab, vol. 5, p. 277; Q. al-Samarrai, The Theme of Ascension in Mystical Writings, p. 34; 'Abd al-Karīm al-Qushayrī, 'Arba'Rasā'il, ed. Q. al-Samarrai (Bagdad, 1969), pp. 9-10, 16; J.S. Trimingham, The Sufi Orders in Islam, (Oxford, 1971), pp. 261, 266; 'Ibrāhīm Basyūnī, al-Imām al-Qushayrī: Sìratuhu, 'Àthāruhu, Madhhabuhu fi al-Tașawwuf, pp. 32-33; R.W. Bulliet, The Patricians of Nishapur, p. 152, 250; A. Schimmel, Mystical Dimensions of Islam, pp. 88, 161-162; H. Halm, "Al-Kushayrī", EI 5 (1986), p. 526; 'Abd al-Karim Al-Qušayri, Das Sendschreiben Al-Qušayrīs über das Sufitum, eingeleitet, übersetzt und kommentiert von R. Gramlich, p. 12, 15; E. Stern, Protection From Sin in al-Qushayri’s Thought, pp. 41-43.

41 In one instance, the name 'Abū al-Fawāris is mentioned close to that of Abū al-Hasan. Meier and al-Samarrai hold that these are two different people, but I hold this is one person, and the name Abū al-Fawāris is Abū al-Hasan's nickname (one may even suggest that in its sound, the nickname may even be hinting at his firāsa, his ability to see the concealed in the other's heart-see below, note 88). The scope of this article is too limited to discuss this issue in the required detail. I will only note several difficulties that confronted Meier, al-Samarrai and Hasan. Who are Abū al-Hasan and Abū al-Fawāris? Are these two names of the same person, or are they two people? How does Abū al-Hasan guide al-Qushayrī in the dhikr, when we know that al-Qushayrī's mentor in the mystical path is al-Daqqāq? F. Meier, "Qušayrī's Tartīb As-sulūk", pp. 7-8; al-Qushayrī, 'Arba' Rasā'il, pp. 12-15; al-Qushayrī, Rasā'il, p. 79, note 1 (mentioned by al-Samarrai in al-Qushayrī, 'Arba' Rasā'il, p. 13). Evidently, the problem that Meier and Al-Samarrai tried to contend with, unsuccessfully I fear, follows from their identification of al-Qushayrī as the author of the Tartīb.

42 F. Meier, "Qušayrī's Tartīb As-sulūk", pp. 27-28.

43 F. Meier, "Qušayrī’s Tartīb As-sulūk”, pp. 15-16. 
states that the murid will learn all details of the appropriate behavior from a shaykh (an eminent teacher in the ways of Sufism). Teaching the dhikr formulas to a murid is the shaykh's role: the shaykh teaches the dhikr only after he has examined the murid's heart through his firāsa faculty (a wondrous capacity of spiritual insight that enables the mystic to distinguish what is hidden in the other's heart $)^{44}$ and found him ready to proceed along the dhikr's path. ${ }^{45}$

The conclusion is that, both according to the Tartīb and according to the Risāla, Abū al-Hasan, who guides the Tartīb's author in the dhikr way, is his teacher. Note, then, that according to al-Qushayrì's own method, he could not have written the Tartīb.

Meier admits that the two names, Abū al-Ḥasan and Abū al-Fawāris (whom he prefers to view as two separate individuals and as al-Qushayrîs friends) do not appear in any of al-Qushayrī's biographies, nor does he offer an acceptable explanation for Abū 'Ali al-Daqqāq's absence from the Tartīb. ${ }^{46}$

\section{A different outlook on the teacher's skills}

According to the Tartīb, the teacher should be a man who has himself gone through the mystical path, has devoted himself only to God and is concerned with nothing else but God. Such a teacher is endowed with strong himma (a mental faculty linked to spiritual concentration), which will help the disciple attain swift and unfailing success. But even a teacher who cannot be entirely trusted concerning his knowledge about God's path can sometimes be adequate, although he will lead his disciple more slowly than the first. ${ }^{47}$ By contrast, al-Qushayrī says in the Wașiyya that if a murid (literally, "seeker") were to become a murād (literally, "wanted") and teach the mystical path before he has shed his human characteristics and all that is flawed in him, he will be separated from mystical truth by a curtain and his teaching will be useless. ${ }^{48}$ We may assume that the murìd who prematurely

44 A chapter is devoted to firāsa in the Risāla; Al-Qushayrī, Risāla, pp. 266-275.

45 Al-Qushayrī, Risāla, pp. 426-428.

46 F. Meier, "Qušayrī's Tartīb As-sulūk”, pp. 7-9.

47 F. Meier, "Qušayrī's Tartīb As-sulūk", pp. 15-16.

48 Al-Qushayrī, Risāla, p. 434. In the edition of the Risāla that I used, there is a grammatical problem. The version there is: "wa-min 'ādāb al-murììn 'an lā yata'arradū li-al-tașaddur 'an yakūna lahum tilmìdhan wa-murídan." In translation: "And among the practices appropriate to novices, it is proper for them not to place themselves at the head [of the people] and [not] to have disciple and 
turns into a murād, as described in the Wașiyya, is the equivalent of the slow teacher described in the Tartīb. ${ }^{49}$ The Tartīb finds this slow teacher useful, even if partially, whereas al-Qushayrī rejects him outright.

It is significant that both in the Tartib and in the Wașiyya, two texts meant as guidance for the Sufi disciple, the authors chose to address the

murid." My translation here relies on the continuation of the passage, where it is explained why muridün should not teach. The problem is that the words "tilmidh and murid," the subject of the sentence in the second part of the translated passage, end with the grammatical case actually pointing to the predicate (tanwin fatḥa for khabar kāna). Al-'Anșārī, the exegete of the Risāla, tries to solve this problem as follows: in his view, the muridun should not try and teach those wishing to reach God. Rather, it is proper for them (the muridūn themselves, the subject of the sentence) to be disciples (the predicate of the sentence). Hence, he reads the first part of the sentence as a negation- "not to place themselves," and the second part as an affirmation - "they themselves should be disciples." He pays no attention to the problem evoked by his explanation-how can the subject be plural while the predicate appears as singular? (it is apparently possible in the course of talking for a sentence to change from singular to plural or vice versa); see Zakariya al-'Anșārī, sharh al-risāla al-qushayriyya, vol. 4, p. 224. The manuscripts also contain another version, as noted by Gramlich, the translator of the Risāla to German, who points to two other manuscripts besides the two editions including the problematic version above. In these two manuscripts, Berlin and Vienna, the disciple and the murid in the sentence indeed appear as a subject case (tanwin damma) thereby dismissing the grammatical difficulty. He understands the sentence as I do, namely, the murīdūn should have no disciple or murīd. See 'Abd al-Karim Al-Qušayri, Das Sendschreiben Al-Qušayrīs über das Sufitum, eingeleitet, übersetzt und kommentiert von R. Gramlich, p. 546. See also p. 18 in Gramlich's introduction.

49 The Risāla supports this hypothesis in two ways. One, the description of the perfect teacher in the Tartīb as one who has devoted himself entirely to Allāh (tajarrada lahu), and is concerned with nothing but God (falā yakūnu mushtaghilan bi-shay'in siwa al-haqq), reminds us in its content of the limitations of human qualities and the shedding of desires to do evil (khumūd bashariyyatihi wa-suqūt 'äfätihi) required in the Wașiyya as a precondition for successful teaching. The second way of supporting this hypothesis appears in the 'Iräda chapter (literally: will, desire - a verbal noun denoting entry into the Sufi way and its pursuit until becoming a Sufi). It is said there that the murād concept is used by Sufis to describe one who has reached the end of the mystical way, ostensibly resembling the first and perfect teacher in the Tartīb-al-Qushayrī, Risāla, pp. 238-239. See also J.A. Mojaddedi, "Legitimizing sufism in al-Qushayri’s Risala", p. 48, n. 45. For a similar explanation of the murād concept in additional Sufi literature see L. Massignon, The Passion of al-Hallaj-Mystic and Martyr of Islam, trans. H. Mason (New Jersey, 1982), vol. 3, p. 41. On the concepts murìd Allāh and murād Alläh in the writings of 'Ahmmad Sirhindī, see Y. Friedmann, Shaykh Ahmad Sirhindī-An Outline of his Thought and $a$ Study of His Image in the Eyes of Posterity, pp. 27, 89. 
option of disciples going to study with a teacher who has not yet completed his mystical training. Clearly, then, learning the mystical way from individuals who had studied it only partially was acceptable, to a greater or lesser extent. Whereas the Tartīb does not reject this option, al-Qushayrī does.

\section{The Sharīa Commandments and the Mystical Path}

The commandments are mentioned in the Tartīb three times. At the opening of the treatise, the teacher forbids the disciple to read the Qur'ān or to perform superegatory performances (nawäfil) except for two. ${ }^{50}$ Elsewhere, the author describes his torments when forced to neglect the dhikr in order to observe the commandments. ${ }^{51}$ Finally, at the end of his mystical path, the annihilation ( $\left.f a n \bar{a}^{\prime}\right)$ experience leads him to miss the time of prayer. ${ }^{52}$ According to this description, observance of the commandments at the beginning of the mystical path appears to be part of life's routine, almost a necessary evil. At the culmination of this path, however, the mystical experience is the essence and the commandments are secondary.

In al-Qushayri's works, the picture is different. ${ }^{53}$ For him, as well as for others, the commandments must always be rigorously observed. ${ }^{54}$ In the

50 F. Meier, “Qušayrī’s Tartīb As-sulūk", pp. 15-16.

51 F. Meier, "Qušayrī's Tartīb As-sulūk", p. 25.

52 F. Meier, "Qušayrī's Tartīb As-sulūk", p. 28.

53 Indeed, on the nawäfil matter, al-Qushayrī's stance in the Wașiyya is close to that of the Tartīb but not identical. After stating that the compulsory commandments must be rigorously observed, he says: fa 'amma al-ziyādāt min al-șalawāt al-nāfila fa-stidāmat al-dhikr bi-al-qalb 'atamm lahum ("as for the addition of discretionary prayers, it is indeed preferable for them to persist in performing the dhikr in the heart")—al-Qushayrī, Risāla, p. 430. In the Tartīb the prohibition is absolute, and the reading of the Qur'ān is also forbidden. In the Risāla, the wording suggests a recommendation, even if strong, and the Qur'ān is not mentioned. This appears to be the more common approach among Sufis, whereby the murid should be accustomed to absolute concentration on God, and all distractions should therefore be forbidden to him, except for the one compelled by religious commandments (though antinomian trends are also known, instructing to refrain from observance of the commandments. Lazarus-Yafeh devoted an article to the issue-H. Lazarus-Yafeh, "ha-mistiqa hamuslemit ve-yahasah la-mitzvot" ("Islamic Mysticism and its Approach to the observance of the Sharī $a$ commandments" [Hebrew]), Molad 18 (1960-1961), pp. 485-488. Hence, both the author of the Tartī and al-Qushayrī seem to have advocated this view, even if with different nuances.

54 Thus, for instance, according to al-Kalābādhī (d. 380/990 or 384/994), even one who has reached fanā' (ecstatic annihilation), "is preserved to perform his 
Risāla this view is endorsed even by Abū Yazīd al-Bisțāmī, whose ecstatic cry "may I be praised" (from the scandalous "shațāhàt" cries, whereby the caller expresses his union with God) is cited in the Tartīb as an expression of the person's self-obliteration within God. ${ }^{55}$ According to al-Qushayrī, Leading Sufis expanded the nawäfil and intensified their ritual reading of the Qur'ān. ${ }^{56}$ Furthermore, rigorous observance of the commandments and abstention from sin are a condition for reaching the high mystical rank, such as al-mahabba (mystical love) or also the rank of the 'ârif (possessor of gnostic mystical knowledge). ${ }^{57}$

duties to God" - See A. Schimmel, Mystical Dimensions of Islam, p. 143. Ghazzzālī's similar stance is well known, as we learn from many chapters of his work 'Ihya $\bar{a}^{\text {' }}$ 'Ulūm aI-Dìn. 'Ahmad Sirhindī also emphasizes that rigorous observance of the commandments is imperative for leading Sufis as well, even those in the highest mystical states, see Y. Friedmann, Shaykh Ahmad Sirhind -An Outline of his Thought and $a$ Study of His Image in the Eyes of Posterity, pp. 41, 45, 48-49, 91. As a prominent example of such Sufis he cites al-Hallāj in p. 49.

55 F. Meier, "Qušayrī's Tartīb As-sulūk", p. 22; al-Qushayrī, Risāla, pp. 38-39, 292 (bāb al-wilāya). See also Lazarus-Yafeh, "Islamic Mysticism and its Approach to the observance of the Sharīa commandments", p. 486. Another example: Al-Junayd was a rigorously observant scholar, see al-Qushayrī, Risāla, pp. 50-51, (perhaps contrary to the view ascribed to him, whereby excessive emphasis on the commandments, on reward and punishment in the world to come and on karāmāt [miracles], separates the chosen hearts from the mystical truth-A. Schimmel, Mystical Dimensions of Islam, p. 211). Further examples: 'Ibrāhīm al-Khawāṣṣ took nothing with him on his travels (apparently because of the tawakkul qualityabsolute trust in God) except for a needle with which to mend his clothes and hide his nakedness, as required by the Sharī'a (p. $3^{23}$ [bāb 'ahkāmihim fíal-safar]); Al-Shibli rigorously observed all legal practices ('àdāb al-sharì'a), however minor, even when facing his death (p. 339 [ bāa 'ahwālihim 'inda al-khurūj min al-dunya]); al-Bistāmī expresses an uncompromizing demand for rigorous observance of the Shari $i a$ as a condition for reaching the high mystical rank (pp. 38-39).

56 For instance: al-Qushayrī, Risāla, pp. 38 (al-Bisțāmī), 51 (al-Junayd), 322323 (bāb 'ahkāmihim fi al-safar); al-Qushayrī, Taḥbìr, p. 64. Al-Junayd engages in the ritual reading of the Qur'àn even at the time of his death, al-Qushayrī, Risāla, p. 335. An interesting example of a Sufi reading of the Qur'ān, which al-Qushayrī does not cite, is the story of Abū Sa'īd ibn Abī al-Khayr who, in his youth, was found by his father reading the Qur'ān throughout the night from beginning to end hanging upside down in the ribāt-R.A. Nicholson, Studies in Islamic Mysticism (Cambridge, 1921), pp. 13-14. But Abū Sa'̄id was also known for his antinomian approach to the commandment of pilgrimage, see Lazarus-Yafeh, "Islamic Mysticism and its Approach to the Observance of the Sharī $a$ Commandments", p. 487.

57 For al-Mahabba - see al-Qushayrī, Risāla, p. 351 (bāb al-Maḥabba); for 'Ārif, see pp. 342, 345 (bāb al-márifa bi-Allāh). 
As for missing prayers, al-Qushayrī explicitly argues against a story of this kind appearing in the Tartīb: mystics at the highest rank are mahfüzūn (safeguarded) by God's grace from any breach of the Sharī $a$, just as prophets are massumūn (protected from sin) by God's grace. This applies also to observance of the prayers. The most eminent mystics will perform their prayers on time, even when sustaining a mystical experience leading them to ecstatic loss of consciousness. ${ }^{58}$

This is the place to emphasize the centrality of this issue for al-Qushayrī. The tension between performing prayers and being in $f a n \bar{a}^{\prime}$ is not unusual among Sufis. When in ecstatic obliteration, the mystic is entirely unaware of existing separately from God and even he himself, as it were, does not exist. Who is the worshiper then? Furthermore, the fan $\bar{a}$ ' is a state of union that eliminates duality between man and God. Observing the commandments, however, requires duality between commander and commanded, and is thus an obstruction in the mystical path. Indeed, Sufis have often been accused of neglecting the commandments of Islam because of their ecstatic behavior. ${ }^{59} \mathrm{Al}$-Qushayri reacts to the Sufis' notoriety in this regard, and at the very beginning of the Risala stresses that neglect of the commandments in general and of prayers in particular is an act of deceitful charlatans who pretend to have reached a high mystical rank. ${ }^{60}$

58 Al-Qushayrī, Risāla, pp. 99-10o (al-tawajjudwa-al-wajdwa-al-wujūd), 292-293 (bāb al-wilāya). The 'awliyā' maḩüzūn-just as al-'anbiyā' ma șümün-see p. 292; Lațā'if, vol. 2, p. 105. See also W. Madelung and E. Tyan, "Ișma", $E I^{2} 4$ (1978), pp. 182-183. On the view that al-Kalābādhī offers on this matter, see A. Schimmel, Mystical Dimensions of Islam, p. 143. 'Aḥmad Sirhindī also uses the concept of mahfüz to indicate the rank of a Sufi at a sublime mystical rank, when he has no contact with the world and is beyond the scope of the shari $a$, but nevertheless does not neglect any detail of the sharí $a$ duties and is safeguarded (mahfüz) from all sin, see Y. Friedmann, Shaykh Ahmad Sirhindi-An Outline of his Thought and a Study of His Image in the Eyes of Posterity, p. 45. See (note 18) also a reference to a view similar to that of Hujwīin (d. 465/1072-46o/1077). The protection from sin is the main subject of my PhD dissertation-E. Stern, Protection From Sin in al-Qushayrï's Thought, The Hebrew University of Jerusalem (Jerusalem 2010).

59 See for instance: Lazarus-Yafeh, "Islamic Mysticism and its Approach to the Observance of the Sharī $a$ Commandments"; A. Schimmel, Mystical Dimensions of Islam, p. 21.

60 Al-Qushayrī, Risāla, pp. 8-9. 


\section{The dhikr in Al-Qushayrì's Treatises and in the Tartīb}

In the Risāla, a chapter is devoted to the dhikr-Bāb al-Dhikr. ${ }^{61}$ This text is the closest to a kind of planned and detailed treatise by al-Qushayri on the subject of the dhikr. Had he also been the author of the Tartīb, we could expect similar dhikr descriptions in the Bāb al-Dhikr and in the Tartīb, but this is not the case. The following details rely on al-Qushayrì's other works as well.

First, I did not find central details described in the Tartīb in al-Qushayrī's texts. Conspicuously absent are the movement and voices of limbs, names of God and endless numbers of dhikr formulations learned in the course of the mystical experience, and the use of a Persian word to refer to God that is mentioned at the end of the Tartīb.

Second, on two central issues the Tartīb and al-Qushayrī present opposite views concerning the performance of the dhikr.

In the Tartīb, the dhikr involves three stages-lisān, qalb, and sirr (see above). This division is known in Sufi literature. ${ }^{62}$ In the Bāb al-Dhikr, however, al-Qushayrī presents only two kinds of dhikr-vocal ("with the tongue") and silent ("in the heart"), ${ }^{63}$ a division that is also well known in Sufi literature. ${ }^{64}$ There is no dhikr al-sirr. ${ }^{65}$ As for the dhikr al-lisān and the dhikr al-qalb, al-Qushayrì's description differs from that in the Tartib. Whereas the Tartīb stresses that the tongue plays no part in the dhikr alqalb, al-Qushayrī claims that the most sublime perfection a mystic can reach in the dhikr is a stage in which the heart and the tongue together recite the dhikr in the fullest and purest way. Also in the Wașiyya the shaykh instructs his disciple to perform the dhikr "with both his tongue and his heart." ${ }^{\prime 66}$ A comparison with additional Sufi texts may reveal that the Tartib

61 Al-Qushayrī, Risāla, pp. 255-26o.

62 L. Gardet, "dhikr", pp. 225-226.

63 Al-Qushayrī, Risāla, p. 256.

64 A. Schimmel, Mystical Dimensions of Islam, p. 171.

65 In some places, al-sirr is indeed mentioned in the context of the dhikr, but only as part of a richer graphic description, an expression of man's hidden depths where, beside his other spiritual "limbs," he undergoes a spiritual experience. The allusion is not to a separate dhikr of the sirr. Al-Qushayrī, Risāla, p. 427 (bāb al-wașiyya li-al-murīdīn); al-Qushayrī, Lațā'if, vol. 1, pp. 217-218.

66 Al-Qushayrī, Risāla, p. 428; all of man's mystical "instruments" - the heart and all its parts (qalb and $f u^{\prime} \bar{a} d$ ), the inner secret, and the spirit-all participate in the dhikr, see Latā'if, vol. 1, pp. 217-218. The exegesis of the Qur'ānic verse "wa dhkur rabbaka kathiran" (in the verse-[3], 41-And mention thy Lord oft, and 
and al-Qushayrī convey two different approaches in dhikr methods, one in which the dhikr is performed in the heart, ${ }^{67}$ and one involving both the heart and the tongue. ${ }^{68}$ Possibly, al-Qushayri is expressing in this regard as well his opposition to charlatans who pretend to a mystical rank they have not attained. He may fear, as he does concerning the tension between the mystical experience and the commandments, that a silent dhikr might indicate that a ritual performed in one's heart is preferable to an actual ritual, thus providing a potential swindling tool. ${ }^{69}$ Al-Qushayrī, however, could merely be transmitting a Sufi tradition about the $d$ hikr method.

give glory at evening and dawn [Arberry's translation]): bi-qalbika wa-lisānika fi jamī awqātika (in your heart and with your tongue at every moment), see p. 242. For an extensive and extremely detailed description of $d h i k r$ and its various kinds of performers, including rich literary features, see, pp. 304-305.

67 Ghazzzālī, Kimiya al-Sa ā da, in Abū Ḥasan Muhammad al-Ghazzālī, al-munqidh min al-ḍāal wa-ma'ahu Kimiya al-Sa'āda wa-al-qawā'id al-'ashara wa-al'adab fíal-dīn (Cairo), p. 88. Hujwīrī describes a dhikr whose words are "Allāh Allāh Allāh," which al-Tustarī taught an advanced disciple. He instructed him to perform this dhikr without articulating any sound and letting the limbs do the dhikrSchimmel, Mystical Dimensions of Islam, p. 169. This disciple's perseverance in the dhikr was extremely impressive. When he was involved in an accident and his head split, his spilling blood traced the shape of the words Allāh Allāh. I found this story twice in al-Qushayri's works, but only its miraculous ending. The dhikr mode performed silently with the limbs was not cited, see al-Qushayrī, Risāla, p. 26o (bābal-dhikr). For a different version concerning the reporter of this tale, see al-Qushayrī, Taḥbīr, p. 23. Najm al-Dīn Kubrā also teaches that, at a certain stage, the tongue has no place in the dhikr, since it will disturb the heart. See Kubrā, Fawā ih al-Jamāl wa-Fawātị̆ al-Jalāl, pp. 214-215. 'Aḥmad Sirhindī forbids performing the dhikr aloud (dhikr-i jahr), since it is incompatible with the practices of the prophet related to the worship of God ( $i b \bar{a} d a)$, see Y. Friedmann, Shaykh Ahmad Sirhindi-An Outline of his Thought and a Study of His Image in the Eyes of Posterity, p. 44.

68 More on the tension between the vocal and the silent dhikr is known in Sufi thought, see H. Algar, "Silent and vocal dhikr in the Naqshbandi order", pp. 39-46; S. Sviri, The Taste of Hidden Things, pp. 124-144; N. Levzion, "Eighteenth century sufi brotherhoods: structural, organisational and ritual changes", in P.G. Riddle and T. Street (eds.), Islam: Essays on Scripture, Thought and Society: A Festschrift in Honour of Anthony H. Jones (Leiden, 1997), pp. 152-153.

69 A saying of al-Junayd in the Risāla may hint to this. In his view, someone engaging in robbery or in zina (illegal sexual intercourse) is preferable to one holding the view advocated by some of the 'arifün (possessors of the gnostic mystical knowledge) whereby refraining from movement (namely, from action) attests to purity of faith-al-Qushayrī, Risāla, p. 345 (bāb al-ma'rifa bi-Allāh). See also J.A. Mojaddedi, "Legitimizing sufism in al-Qushayri's Risala", p. 46. On the link 


\section{Satan's Incitements}

In the Tartīb, Satan (al-shaytān) is ascribed a crucial role. Satan is the only evil authority intervening in the life of every man to lead him astray. Those who are at low spiritual ranks, he incites to neglect the commandments. Those at high religious levels, he tempts through cunning tricks, even calling upon them to observe the commandments. To lure eminent mystics, Satan even uses the mystical experience. He creates a powerful mystical experience that will distract them from God. This experience may be accompanied by spiritual music, which may at times surpass the music coming from God. ${ }^{70}$ No one is protected from Satan. Mystics at the highest ranks might be able to discern a satanic mystical experience. In their hearts is a God-given spiritual state that serves them to test the nature of new mystical states they experience. If a new mystical state evokes in them a harmonious sense of closeness and intimacy ('uns), they will know its source is divine. If the new state evokes in them the anguish of loneliness (wahsha), pain, and the sense of revulsion elicited by the tasting of foul food, they will discern the sharp contrast between the new state and the spiritual state already within them and will know the new one comes from Satan. Nevertheless, Satan's very ability to reach them attests to his powers. ${ }^{71}$

Satan is described as an independent power competing with God, cunning and plotting, with quasi-human motives.

Al-Qushayrī's descriptions of Satan are different. He has two namesShaytān and 'Iblīs. Sometimes, satanic brigades (junūd) he commands appear with him. Among the recurring stories about him: the Garden of Eden and the expulsion from it, when Satan was demoted from his angelic rank to his cursed status; his contacts with prophets, eminent men, and

between dhikr (at least concerning the appearance of the concept in the Qur'ān) and ritual prayer according to Muqātil's view, see P. Nwyia, Exegese Coranique et Langage Mystique (Beyrouth, 1970), p. 36. 70.

70 F. Meier, "Qušayrī's Tartīb As-sulūk", pp. 22-24.

71 F. Meier, "Qušayrī’s Tartīb As-sulūk", pp. 22-24. The slight similarity between this description and that of Saint Therese concerning the distinction between a heavenly vision and the deceits of the soul and of Satan is worth notingW. James, The Varieties of Religious Experience (London, 1961), p. 35. On a mystical satanic occurrence experienced as divine mystical experience among fourth century Christian monks, see A. Kleinberg, Fra Jinepros Leg of Pork [Hebrew], (Tel-Aviv, 200o), pp. 167-168. 
mystics. Satan is also mentioned in stories and sayings about morality and religious piety as an intimation of evil, at times inciting, of which one must beware. Such descriptions are common in Sufi literature. ${ }^{72}$ In the texts I read, I did not find Satan intervening in human consciousness as a forger of the mystical experience. Nor did I encounter inner mystical music, of which he is the source.

In al-Qushayrî's view, Satan is not the only force inciting evil. The lower soul_al-nafs — is also active in leading human beings away from righteousness, and I have already noted its absence from the Tartīb.

As for the eminent mystics, Satan cannot draw close to them since their heart is protected from him. When drawing close to a man in the midst of the dhikr and overcome by a mystical experience, Satan will be swiftly beaten to the ground, helpless. At times, a kind of light shines from the hearts of mystics and burns up Satan when he tries to approach. ${ }^{73}$ At times, a pure intention, a meek heart, and religious genuineness will suffice to prevent Satan from approaching. ${ }^{74}$

72 Examples of Satan in al-Qushayrī's works: the fall of Satan-see Latā'if, vol. 1, p. 365; vol. 3, p. 333; Nüh (Noah) is ordered to take him into the ark at the time of the flood-see: vol. 2, p. 137; the Satans bow to King Solomon's authority-see vol. 3, pp. 40-41; Mirräj, p. 105; his contacts with mystics—see Lațäiff, vol. 1, p. 599. Other sources: A. Schimmel, Mystical Dimensions of Islam, pp. 193-195; P.J. Awn, Satan's Tragedy and Redemption, (Leiden, 1983), p. 10. Among the common motifs are Satan dressing up as a man and the temptation to do evil by persuading someone to observe a commandment, see P.J. Awn, Satan's Tragedy and Redemption, pp. 10, 48-49, 79-84. Al-Qushayrī cites a story of this kind from the qișaș literaturethe story of Qārūn (Korah). Qārūn was a servant of God living an ascetic life. 'Iblīs (Satan) joined him in his monastic cell disguised as a man, and worshipped God with him. Gradually, through trickery and adducing arguments of charity and piety, he persuaded Qārūn to accumulate money, at first occasionally and finally as a set practice. He finally brought him to love his wealth, and this love brought Qārūn to his end-he was swallowed by the earth for his sins. See al-Qushayrī, Lațầif, vol. 3, pp. 79-8o. For various traditions discussing the possible origins of 'Iblis (was he originally a jinn or an angel), and traditions describing the expulsion from the Garden of Eden see: P. Awn, Satan's Tragedy and Redemption, pp. 20-24, 27-31; M.J. Kister, "'Ādam: A Study of Some Legends in Tafsìr and Hadīt Literature", Israel Oriental Studies 13 (1993), pp. 116, 122-124; E. Stern, Protection From Sin in al-Qushayrìs Thought, pp. 36, 166-167.

73 Al-Qushayrī, Lațā'if, vol. 1, p. 599, vol. 2, p. 265; al-Qushayrī, Risāla, p. 260 (bāb al-dhikr), and see also p. 344 (bāb al-márifa bi-Allah).

74 Al-Qushayrī, Risāla, p. 179 (bāb al-jaw`wa-tark al-shahwa); al-Qushayrī, Taḥbìr, p. 22. This view is not specific to al-Qushayrī, and its foundations are already found in the Hadith, see P.J. Awn, Satan's Tragedy and Redemption, pp. 51, 75-76. 
The wașiyya as opposed to the Tartīb

In the wasiyya chapter, al-Qushayri indeed challenges the position of the Tartīb. He describes sudden thoughts and damaging voices the disciple hears in the course of the dhikr and on other occasions. The voices and the thoughts are so ugly that one cannot even dare to express them. To struggle against them, the disciple must turn his mind away from them, seek God's protection and persevere in the dhikr; more significantly - the disciple must know they are not from Satan but solely from hawajis al-nafs (the prompting of the lower soul) $!^{75}$ Satan, then, is explicitly denied any role concerning the very experiences the Tartîb claims he creates. These bad thoughts are obviously extremely harsh and they imply an affront to God's holiness, since al-Qushayri emphasizes that God is free from the imperfection (munazzah) emerging from what is found in them, and even the thinker himself is aware of that. It also appears that they affect the murid against his will. Popular views would plausibly ascribe such thoughts to Satan. Al-Qushayrī seems to know this, and insists on warning the disciple against this perception. The Tartīb, then, conveys a view that al-Qushayri explicitly opposes. ${ }^{76}$

\section{A Proposal on the Origin of the Tartīb}

Close associations with the Tartīb are evident in Fawāih al-Jamāl waFawātih al-Jalāl (henceforth Fawā̄ih), a treatise by Najm al-Dīn Kubrā

75 Al-Qushayrī, Risāla, pp. 428-429.

76 Although the Wașiyya cites al-Bisțāmī's saying: "Whoever has no teacher, Satan is his 'imām" (man lam yakun lahu ustādh fa'imāmuhu al-shayțān), see al-Qushayrī, Risāla, p. 426. The context of this saying, however, is ethicalpsychological rather than experiential-mystical, since it is cited to illustrate the claim that he who has no teacher is a slave of his passions. No connection is assumed in the text between this saying and the mystical experience. Furthermore, this saying probably served as a kind of folk parable, since it is also known as a popular saying in modern Egypt, see Muhammad Ḥasan Haykal, Zaynab-Manäzil wa-'akhlāq Riffyya (Cairo, 1967), p. 258. It appears that 'Ahmad Sirhindī's saying, whereby an ignorant Sufi is Satan's fool (see Y. Friedmann, Shaykh Ahmad Sirhindi- -An Outline of his Thought and a Study of His Image in the Eyes of Posterity, p. 41), should be understood in a similar spirit. Compare also to the Bektashi poem, whereby if you have a teacher you could become a human being, but if you have no teacher you will remain an animal-J.K. Birge, The Bektashi Order of Dervishes (LondonHartford-Conn, 1937), p. 97. 
(d. 617/1220). Kubrā, who received his Sufi training from two disciples of Abū Najīb al-Suhrawardī (d. 563/1168), had many disciples, some of whom became influential in the world of Sufi thought. ${ }^{77}$ An order associated with him was prevalent in Khurasan and in Central Asia during the Mongol period. 78

The style of the Fawäih is not similar to that of the Tartīb. Its rich language, the many details it provides concerning the mystical path it presents and the complexity of its descriptions certainly place it at a level higher than the Tartīb. The Fawa'sh belongs to the genre of scholarly religious literature, as attested by the Qur'ān verses, the Hadīth sayings, the stories of celebrated mystics, and the poetry quoted in it. Nevertheless, in some of its contents, the Fawä $i h$ is extremely close to the Tartīb.

A full discussion of Kubrā's potential influence on the Tartīb is beyond the scope of this paper. I will only cite several parallels, which do not appear in this form in al-Qushayrī, in the hope that more detailed research in the future may allow us to identify additional sources of influence on the Tartīb.

- The dhikr. There are three forms of dhikr-lisān, qalb, and sirr. ${ }^{79}$ During the dhikr al-qalb, the tongue is silent, and the other limbs participate through voices and involuntary movement. ${ }^{80}$ The universe and all that is within it are experienced as uttering religious calls. Feelings of growth and contraction are also experienced. ${ }^{81}$ Beside a dimming of the physical senses and the intensification of the senses of the heart, the mystic is also unable to sleep. ${ }^{82}$ Solitude evokes the terror of death. ${ }^{83}$ Food and various tastes are sensed in the mouth. ${ }^{84}$

77 H. Algar, "Kubrā", $E I^{2} 5$ (1986), pp. 300-301; F. Sobieroj, "Al-Suhrawardīi Abu 'l-nadjib", $E I^{2} 9$ (1997), p. 778; F. Sobieroj, "Suhrawardiyya”, $E I^{2} 9$ (1997), p. 784; Kubrā, Fawāìh, p. 67 .

78 H. Algar, "Kubrā"; D. DeWeese, "The Eclipse of the Kubrāvīyah in Central Asia", Iranian Studies 21, No. 1/2 (1988), pp. 45-83. I thank Prof. Michal Biran for the reference to the article of DeWeese.

79 Kubrā, Fawāih, p. 160.

80 Kubrā, Fawā'ih, pp. 155-159.

81 Kubrā, Fawāih, pp. 250-258.

82 Kubrā, Fawā̄ih, pp. 209-210.

83 Kubrā, Fawāìn, pp. 155-156. Interestingly, the Tartīb cites a teacher who escapes from solitude because of this terror, see F. Meier, "Qušayrì's Tartīb As-sulūk", p. 21.

84 Kubrā, Fawä’ih, pp. 149, 154-155, 157, 163, 170-171. 
- The names of God. Dhikr formulations and divine names learned in its course, unknown to any person or any angel, are mentioned in the Tartīb. Kubrā notes that a name for God is revealed to every waliyy, a name known only to him. ${ }^{85}$

- Satan's Incitements. Satan is close and plotting, as in the Tartïb, using a call to do good as a tool for leading the righteous astray. ${ }^{86} \mathrm{He}$ creates deceptive mystical experiences, in which music is sometimes heard. Only those at the highest rank can distinguish between a divine and a satanic experience, by comparing experiences of sweet and bitter tastes. ${ }^{87}$

- Between teacher and disciple: Dream and himma. The Tartïb illustrates the intimacy prevalent between the author and his teacher through a dream, wherein the author's reflections when awake were woven into the dream of his sleeping mentor. ${ }^{88}$ Kubrā's teacher also dreams such a dream, and is happy to discover that the mystical experience of his wakeful disciple has been woven into the plot of his own dream. ${ }^{89}$

85 F. Meier, "Qušayrī's Tartīb As-sulūk", p. 18; Kubrā, Fawā’ih, pp. 251-252. According to Kubrā, all these names are included together in the category of 'ism Allāh al-'a'zam (the greatest of God's names). He points to names in a language that is not Arabic and attempts to explain them. These names are not the ninetynine names of God known in Islamic literature and extensively discussed in many works, among them al-Qushayrī's al-Taḥbìr.

86 Satan harassed Kubrā himself to divert him from his mystical course, and with great sophistication: Kubrā's idea of writing a book against Satan's incitements was revealed, through his shakh's counsel, as a satanic plot to divert him from his mystical path, see Kubrā, Fawā'ih, pp. 143-144.

87 On deceitful experiences that include various sounds and music, see Kubrā, Fawä'ih, pp. 155-157; on the place of taste, see p. 145 .

88 The teacher's nickname, Abū al-Fawāris, could remind in its sound (though not necessarily in its literal meaning) the firāsa (the mystical ability to discern what is hidden in the other's heart), one of the wondrous acts (karamāt) for which the greatest Sufis became famous. His possession of such powers is intimated in the story of the dream. On the night of the festival, the teacher and the author are in the mosque. The teacher is sleeping. The author is pondering about the samn (butter). At the same time, the teacher dreams that God is about to be revealed to them in a high place, the people are in a mystical state of hayba (literally: awe), whereas his disciple is concerned about the samn in his hand. In his dream, the teacher rebukes his disciple and tells him to drop the samn. This rebuke is articulated aloud, while the teacher is asleep, and is heard by the wakeful authorF. Meier, "Qušayrī's Tartīb As-sulūk", p. 27.

89 In his dream, the teacher walks around Mecca with Kubrā. Kubrā points to a sun they both see, and says that the sun and Kubrā are one. During the dream, 
The use of the himma as a training device is the good teacher's virtue in the Tartīb. Kubrā describes how his teacher's himma inescapably overtook him, to the point that he could sense him at a distance. ${ }^{90}$

- General characteristic. The Tartīb and Kubrā's book almost never deal with morality, law, or theology — concerns typical of al-Qushayrī beside his mystical speculations. Both these treatises are mainly devoted to stages along the mystical path and to the mental and physical experiences characterizing these stages.

\section{Summary}

Although Kubrā cannot be assumed to be the author of the Tartīb, the features common to these two works regarding the dhikr indicate that both are part of the same mystical trend. The Tartīb could be the product of a course taught in a ribāt (a place for Sufi residence, practice, and ritual) by a teacher belonging to the order associated with Kubrā. The course was delivered orally. The teacher was probably a lesser figure than Kubrā in his knowledge, his education, and his literary impact. But the material of the course, namely, the guidelines of the mystical path whose main expression is the dhikr, rests on Kubrā's doctrine. ${ }^{91}$

The Tartīb is apparently a recording of lessons delivered in a ribatt. The recording may have been the work of a student, as an auxiliary device for instruction in the mystical way of the dhikr. The main evidence for this is in its language, a shallow literary Arabic at times close to the spoken

Kubrā actually experiences a mystical state, where he indeed senses he has been united with the sun-Kubrā, Fawā'ih, p. 164.

90 Kubrā, Fawā'ih, p. 237.

91 After reading my study, Prof. Etan Kohlberg directed my attention to the fact that Meier, in his study of Kubrā (F. Meier, Die Fawāih al-Ğamāl wa-Fawāt'ih al-Ğalāl des Nağm ad-Dīn al-Kubrā [Wiesbaden, 1957]), pointed to several parallels between the Fawā'ih al-Jamāl wa-Fawātih al-Jalāl and the Tartīb. Meier related generally to the actual appearance of supernatural phenomena in both these works (p. 242). He mentions (p. 204) the similarity between them concerning the obliteration of the mystic's consciousness, although he does note that Kubrā does not depend for this on the Tartīb (for him, on Al-Qushayrī). He attempts a more specific comparison between them concerning the dhikr performed through the active and conscious initiative of the disciple as opposed to a dhikr where the disciple remains passive (p. 209). He also examines several parallels and contrasts concerning a dhikr accompanied by movements of the limbs and concerning the participation of nature in the dhikr (pp. 208-210). 
language. ${ }^{92}$ Even Persian is used to denote God's name (Khuday) and for indicating numbers. ${ }^{93}$ The use of associative language is also evident. ${ }^{94}$ Furthermore, the oral delivery obviously takes place within a group who knows the author and his teacher, Abū al-Hasan, or as he was known by what I believe to be his nickname, Abū al-Fawāris. The author relates events that happened to both of them, while alluding to the deep intimacy between them as if it were familiar to his listeners. The only identifying details the author notes about his teacher are his name and nickname. Even the fact that this was his teacher emerges only from the content of the stories. The author, then, speaks about a person who is already known to the audience-probably an ordinary matter in the life of the ribāt.

92 An interesting example: in the author's personal stories, we find twice the negative conjunction lākinnani (as well as lākinni), which means "but I," instead of an expression meant to denote identity. See F. Meier, "Qušayrī's Tartīb As-sulūk", pp. 27-28 (although a copier's mistake is possible in this instance).

93 F. Meier, "Qušayrī's Tartīb As-sulūk", p. 23.

94 A prominent example: details about stages in the mystical way are discussed out of context, when discussing other matters, without any indication of a transition between topics. Characteristic features of the dhikr al-qalb are twice cited in a discussion of the dhikr al-sirr (F. Meier, "Qušayrī's Tartīb As-sulūk", p. 17). A feature typical of the dhikr al-qalb is once cited in a discussion of the dhikr al-lisān (p. 19), whereas a characteristic of the dhikr al-lisān is cited once in a discussion of the dhikral-qalb (p. 2o). 